\title{
Open reduction of a traumatic left scapulohumeral luxation in a degu (Octodon degus) - a case report
}

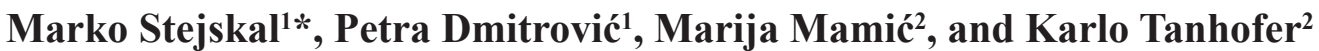 \\ ${ }^{I}$ Clinic for Surgery, Orthopedics and Ophthalmology, Faculty of Veterinary Medicine, University of Zagreb, \\ Zagreb, Croatia \\ ${ }^{2}$ Faculty of Veterinary Medicine, University of Zagreb, Zagreb, Croatia
}

STEJSKAL, M., P. DMITROVIĆ, M. MAMIĆ, K. TANHOFER: Open reduction of a traumatic left scapulohumeral luxation in a degu (Octodon degus) - a case report. Vet. arhiv 90, 213-216, 2020.

ABSTRACT

This report describes a straightforward surgical technique for open treatment of a scapulohumeral joint derangement in a very small patient. A case of an open repair of a traumatic left scapulohumeral luxation in a degu (Octodon degus) with a synthetic ligament is described. The progress of healing was monitored clinically and radiographically. Seroma formation two weeks postoperatively was the only minor complication recorded. There were no major complications. The patient started using the limb 19 days postoperatively and full return of function was achieved within 60 days.

Key words: degu; shoulder luxation; open reduction

\section{Introduction}

Degus (Octodon degus) are members of the Octodontidae family. They are native to the west slopes of the Andes in northern and central Chile (NOWAK, 1999). Degus are commonly used as an animal model for research into many disease processes such as diabetes mellitus, cataracts, and Alzheimer's disease. They are also popular pets, creating a growing demand for the veterinary services. Most problems presented to veterinarians are dental diseases, dermatological issues, gastrointestinal problems, and skeletal disease, usually caused by trauma. This paper describes the luxation of a left scapulohumeral joint, repaired with a modified Campbell prosthetic suture. To the authors' knowledge, this is the first published description of an open scapulohumeral repair in a degu.

\section{Materials and methods}

A two-year-old grey female degu, weighing 230 $\mathrm{g}$, presented with non-weight bearing left thoracic limb lameness a day after its leg was caught on its cage. Physical examination revealed abnormal and significantly increased mobility of the left scapulohumeral joint in both craniocaudal and mediolateral directions, with suspected luxation/ joint derangement. The remainder of the physical examination was unremarkable. Orthogonal radiographs confirmed the clinical diagnosis. The lateral view of the left shoulder region showed both cranial and caudal scapulohumeral luxation, supporting the diagnosis of a deranged joint (ROCHAT, 2012; Figs 1 and 2).

\footnotetext{
*Corresponding author:

Marko Stejskal, DMV, PhD, DACVS-SA, DECVS, Clinic for Surgery, Orthopedics and Ophthalmology, Faculty of Veterinary Medicine, University of Zagreb, Heinzelova 55, 10000 Zagreb, Croatia, Phone: +385 912390 546; E-mail: mstejskal@vef.hr
} 


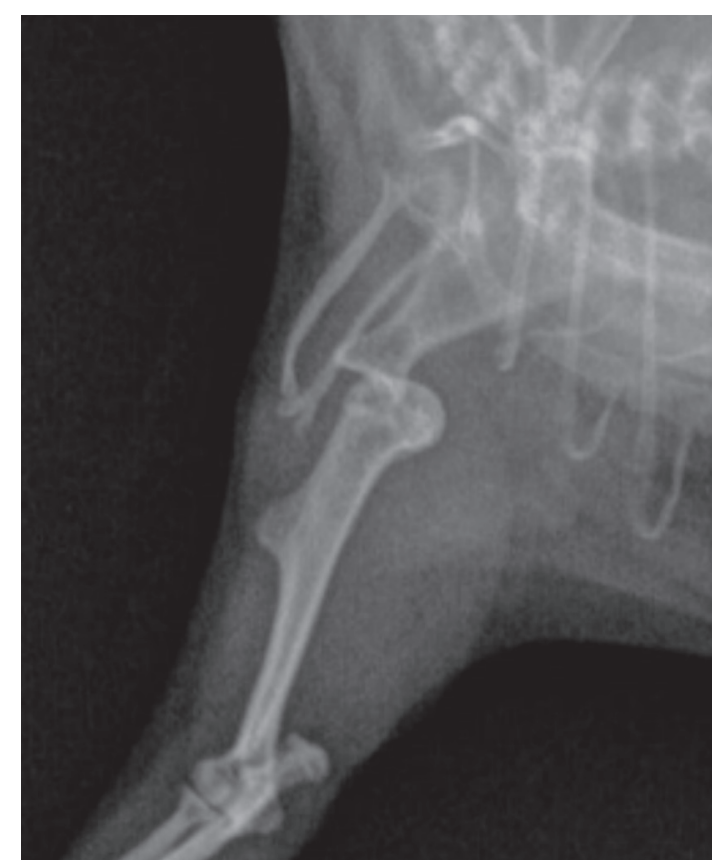

Fig. 1. Lateral view of the left shoulder region showing caudal scapulohumeral luxation

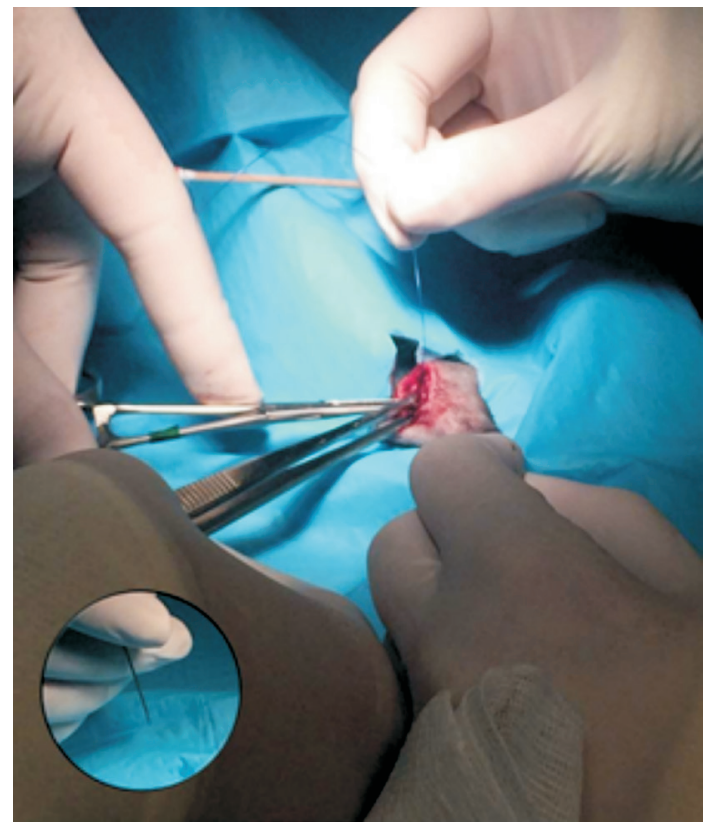

Fig. 3. Modified Campbell's technique for reconstruction of the glenohumeral ligament. Inlet showing hypodermic needle used to pass the synthetic ligament through bone tunnels.

With the owner's compliance, the animal was placed in an induction box and anesthetized with $5 \%$ sevoflurane ("Sevoflurane, USP", Baxter, Deerfield, USA) in oxygen at $3 \mathrm{~L} / \mathrm{min}$ until effect.

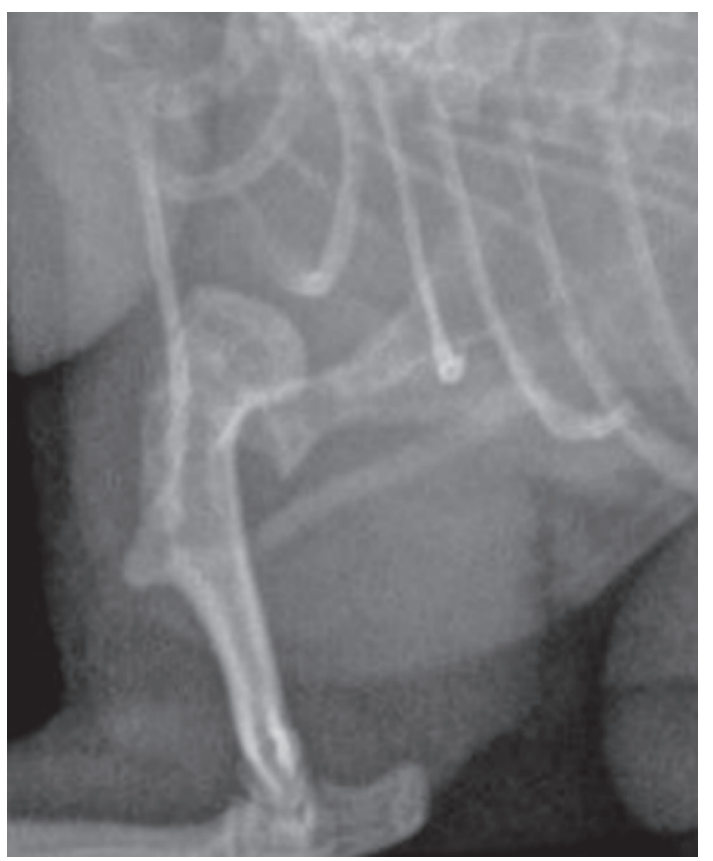

Fig. 2. Lateral view of the left shoulder region showing caudal scapulohumeral luxation

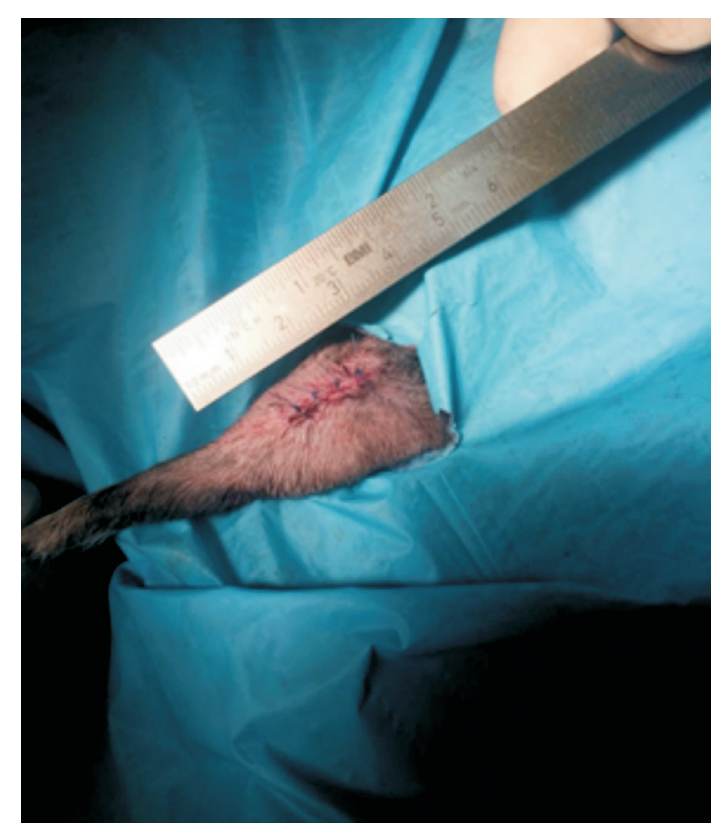

Fig. 4. Skin closure

A closed reduction was attempted, but the joint remained grossly unstable. Meloxicam $0.2 \mathrm{mg} /$ $\mathrm{kg} \mathrm{s} / \mathrm{c}$ ("Meloxidolor" $5 \mathrm{mg} / \mathrm{mL}$, Genera d.d., Kalinovica, Croatia) was administered for pain 


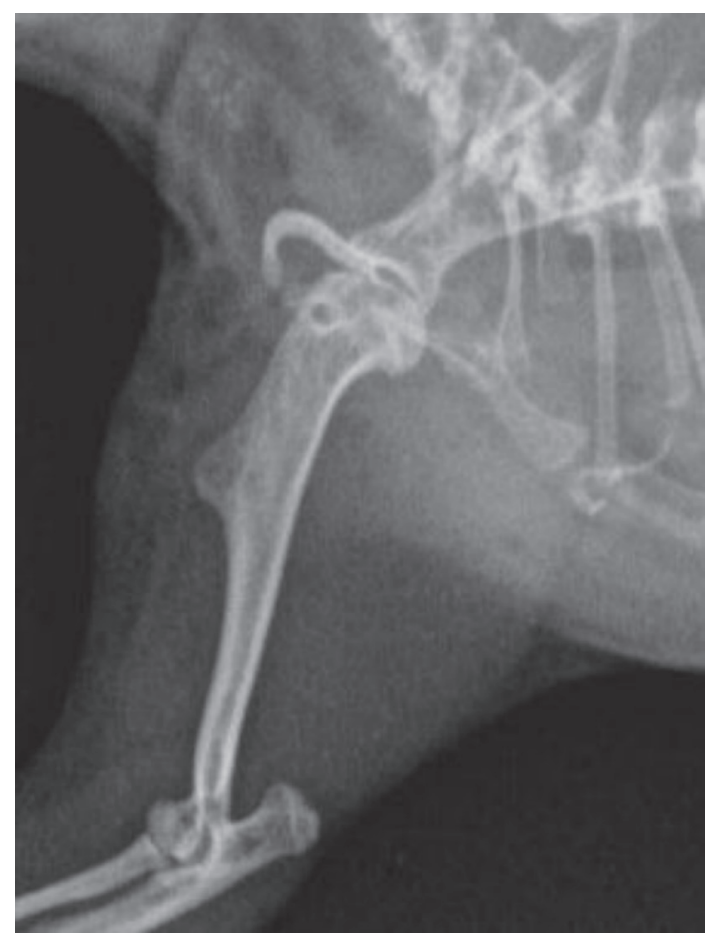

Fig. 5. Immediate postoperative radiograph showing appropriate reduction

management. After discussing potential anesthetic and surgical risks and complications with the owner, the decision was made to proceed with open reduction and stabilization. Surgery was performed six days later under general inhalational anesthesia. The patient was premedicated with medetomidine $0.1 \mathrm{mg} / \mathrm{kg}$ i $/ \mathrm{m}$ ("Sedastart" $1 \mathrm{mg} / \mathrm{mL}$, Genera d.d., Kalinovica, Croatia) and butorphanol $0.4 \mathrm{mg} / \mathrm{kg}$ $\mathrm{i} / \mathrm{m}$ ("Butomidor" $10 \mathrm{mg} / \mathrm{mL}$, Richter Pharma, Weis, Austria), induced and maintained with 6-7\% sevoflurane in oxygen at $3 \mathrm{~L} / \mathrm{min}$. The patient was placed on a heating pad and the operating field was aseptically prepared for surgery. For precision purposes, the surgery was performed with the aid of $\times 2.5$ magnification loupes. A craniolateral approach to the left shoulder was made (PIERMATTEI and JOHNSON, 2004); the luxation was reduced and maintained with Brown-Adson tissue forceps acting as bone holding forceps. Two lateral-to-medial tunnels were drilled with a $1.1 \mathrm{~mm}$ drill bit at the approximated scapular and humeral attachment sites of the lateral glenohumeral ligament. Using a $0.7 \times 38 \mathrm{~mm}$ hypodermic needle, single loop 2-0 nylon (Dermalon, Covidien) was anchored through

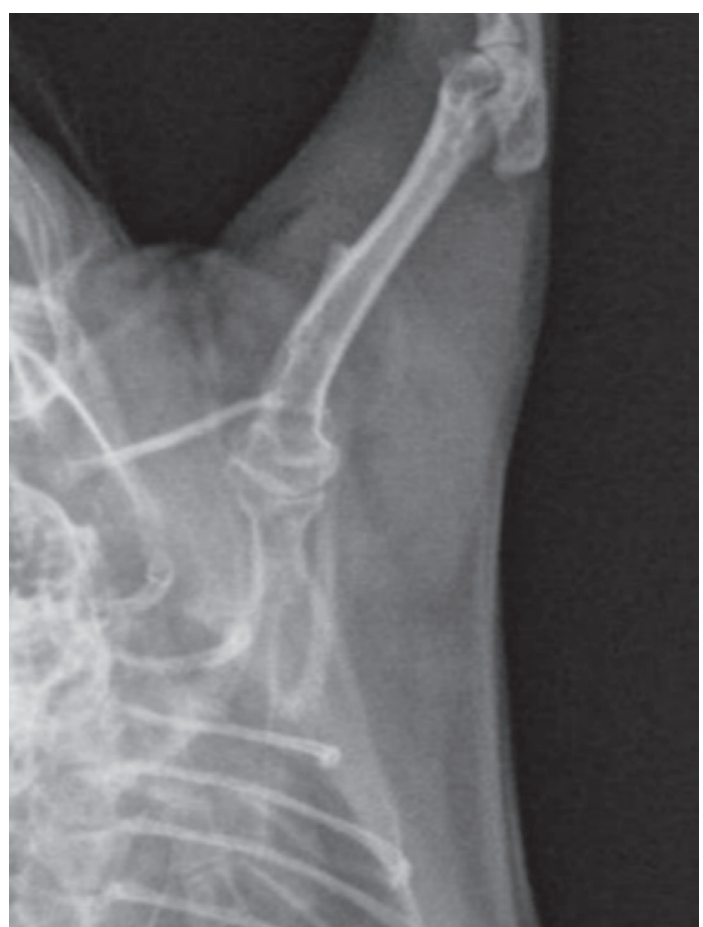

Fig. 6. Immediate postoperative radiograph showing appropriate reduction

the bone tunnels as a synthetic ligament using a modified Campbell's technique to reconstruct the glenohumeral ligament (CAMPBELL, 1968; ROCHAT, 2012; Fig. 3).

The muscles were closed with polyglyconate 4-0 (Maxon, Covidien) and the subcutis was closed with polydioxanone 5-0 (PDS II, Ethicon), both in a simple continuous pattern. The skin was closed with nylon 4-0 (Dermalon, Covidien) in a simple interrupted pattern (Fig. 4). The immediate postoperative radiographs showed the appropriate reduction (Figs 5 and 6). The patient was discharged the same day with 5 days' worth of meloxicam at $0.2 \mathrm{mg} / \mathrm{kg} \mathrm{s} / \mathrm{c}$ every 24 hours. The recovery was monitored clinically on a weekly basis.

The patient started toe-touching within two days. Skin sutures were removed two weeks after surgery. At that time a small seroma was noted at the distal end of the incision, which required no further treatment. Four-week recheck radiographs showed the unchanged reduction. Nineteen days after surgery the shoulder joint had a normal range of motion compared to the contralateral side, and the function of the leg was recovering. Two 
months postoperatively, full return of function was observed.

\section{Discussion}

Traumatic shoulder luxation is an uncommon condition. On physical examination, an abnormal relationship between the acromion and the greater tubercle may be detected. Orthogonal radiographs usually confirm the luxation. Treatment options include closed and open reduction. Closed reduction and immobilization with a spica splint were deemed unrealistic and prone to splint related complications, risking the compromise of the blood supply in particular. Surgical techniques include reconstruction or augmentation of the glenohumeral ligament and joint capsule, transposition of the biceps brachii or the supraspinatus muscle tendon, modified Campbell prosthetic sutures, and temporary transarticular fixation. Salvage procedures, such as arthrodesis and excision arthroplasty, could also be considered (ROCHAT, 2012). Searching for the simplest and least invasive surgical technique, a modified Campbell prosthetic suture was chosen. This procedure uses a heavy suture passed through transverse tunnels in the humeral head and the scapular neck, to create or augment glenohumeral ligaments (CAMPBELL, 1968). The tunnels should be drilled at the attachment sites of the lateral glenohumeral ligament. The major challenge of this procedure was the small size of both the animal and the operating field. The precision of the execution on such small bones was significantly improved by using $\times 2.5$ magnification surgical loupes. Control of the humerus and the scapula was achieved with Brown-Adson tissue forceps, as there were no bone holding forceps available of an appropriately small size. Other basic surgical instruments, such as curved hemostats, could also be used, according to the surgeon's preference.

This brief report describes a straight forward surgical technique and some practical solutions for open treatment of a scapulohumeral joint derangement in a very small patient. We believe that some of the technical solutions described could be extrapolated to similar clinical scenarios, offering a better chance for fully functional outcome for patients whose small size should not prevent practitioners from providing them with the most efficient treatment options.

\section{References}

CAMPBELL, J. R. (1968): Shoulder lameness in the dog. J. Small Anim. Pract. 9, 189-198.

NOWAK, R. M. (1999): Walker's Mammals of the World. $6^{\text {th }}$ ed., Vol II. The Johns Hopkins University Press, Baltimore, MD, p. 1936.

PIERMATTEI, D. L., K. A. JOHNSON (2004): An atlas of surgical approaches to the bones and joints of the dog and cat. $4^{\text {th }}$ ed., Elsevier Saunders, Philadelphia, pp. 112-118.

ROCHAT, M. C. (2012): The shoulder. In: Veterinary Surgery: Small Animal. (Tobias, K. M., S. A. Johnston, Eds.), Elsevier Saunders, St. Louis, p. 706.

Received: 9 May 2018

Accepted: 27 February 2020

STEJSKAL, M., P. DMITROVIĆ, M. MAMIĆ, K. TANHOFER: Kirurško liječenje traumatske luksacije lijevoga skapulohumeralnog zgloba u degua - prikaz slučaja. Vet. arhiv 90, 213-216, 2020.

\section{SAŽETAK}

Ovaj izvještaj opisuje jednostavnu kiruršku tehniku liječenja traumatskog iščašenja skapulohumeralnog zgloba u vrlo malog pacijenta. Prikazan je slučaj traumatske luksacije lijevoga skapulohumeralnog zgloba u degua (Octogon degus) sintetičkim ligamentom. Proces cijeljenja praćen je klinički i rendgenski. Jedina zabilježena manja komplikacija bio je nastanak seroma dva tjedna nakon operacije. Nije bilo većih komplikacija. Pacijent se počeo služiti nogom 19 dana nakon operacije, a pun povratak funkcije postignut je unutar 60 dana.

Ključne riječi: degu; iščašenje ramena; kirurško liječenje 